\title{
OBITUARIES
}

\section{H.M. GUSTAF VI ADOLF, KING OF SWEDEN}

The very sincere sympathy of the Society is extended to the Swedish people in the loss of their King at the great age of ninety. He was our most distinguished Foreign Extraordinary Fellow.

Gustaf VI Adolf, K.G., King of Sweden, of the Goths and the Wends, will always occupy a very special place in the memories and affections of Orientalists all over the world. He was approaching the age of seventy when he succeeded to the throne in 1950, and the leisure of his long period as Crown Prince had been largely occupied in the formation of a magnificent collection of Chinese art, published in 1948 in a sumptuous volume under the distinguished editorship of Nils Palmgren.

His Majesty had displayed a keen interest in a wide range of cultural subjects since his student days at Uppsala University, where his studies included history, Nordic archaeology, and Egyptology. He was an active patron and supporter of Swedish cultural and archaeological activities abroad, such as the establishment of the Swedish Institutes in Rome and Athens, and the prosecution of archaeological research by Swedish expeditions to Italy, Greece, Cyprus, and China.

It was about 1907 that his personal interests became focused on China, beginning with the pottery of the Ch'ing dynasty; but he was soon attracted to the earlier periods, and it was in these that his collection eventually became pre-eminent, the range of early jades and belthooks being especially noteworthy.

All museum men in this country who are concerned with Chinese art will have lively and affectionate memories of His Majesty's informal visits, sometimes at a moment's notice, and of the friendly and invariably stimulating discussions they involved-the careful assessment and comparison of objects, and the frank and easy exchange of views. We mourn him sincerely as a distinguished Orientalist and a candid friend.

B. W. RoBINSON.

\section{ACADEMICIAN GIORGI TSERETELI}

By the death of Professor Giorgi Tsereteli at Tbilisi in September, 1973, after a short but painful illness, the Society has lost one of its most universally respected, and also gracious and unassuming Honorary Fellows. As well as being Director of the Oriental Institute of the Georgian Academy of Sciences, Tsereteli was a full Academician of the all-Union Soviet Academy in Moscow, and an Honorary Member of the Polish Oriental Society.

Giorgi Tsereteli was born in Tianeti, Georgia, on 21 October, 1904, and attended the Georgian Gymnasium at Kutaisi before entering Tbilisi University in 1922. Seven years later he was transferred to Leningrad, where he worked under Krachkovsky, Kokovtsov, and Barthold. In 1932, Tsereteli was appointed Docent at Leningrad, and gave courses of Arabic there.

Returning to Tbilisi, Tsereteli was appointed in 1936 head of the Oriental Section of the Marr Institute of Language, History, and Material Culture. He devoted himself with outstanding success to building up a Georgian school of Semitic and Islamic studies, and in 1942 was appointed a Professor of Tbilisi University. In 1946 he became a full member of the Georgian Academy of Sciences, and in 1968 (a rare distinction) of the Moscow Academy also. 